Paediatrica Indonesiana 14 : 85 - 91. May - June 1974.

From the Department of Child Health, Medical School, University of Indonesia, Jakarta

\title{
The Treatment of Bronchopneumonia in Children With Urfamycin.
}

\author{
by \\ HARRY HARDJATNO CH., A.H. TAGOR, ALI ASFAR \\ B.M. AKIF and M. SUTAN ASSIN
}

\section{Introduction}

Urfamycin or thiamphenicol is a broad-spectrum antibiotic, which is not inactivated in the body, and is always present in the active form with particularly high sustained levels in the liver-bile and kidney-urine compartments.

Courtieu et al. (1961) described the results of inhibition by thiamphenicol of 344 bacterial strains belonging to some twenty different genera or species and compared them with those obtained with chloramphenicol; they used a method of serial dilutions in an appropriate medium, and obtained the following results:

- Strains of E. coli and Shigella sonnei were frequently more sensitive to thiamphenicol;

- Strains of Bordetella pertussis were equally sensitive to both antibiotics;
- Strains of E. colj isolated from cases of infantile gastro-enteritis appeared to be more sensitive to chloramphenicol, but were frequently resistant to both antibiotics. Thïs can probably be explained by the fact that chloramphenicol is widely used prophylactically.

Onily one strain of E. coli isolated from cases of urinary infections was resistant to chloramphenicol and thiamphenicol.

Shigella dysenteriae and Shigella flexneri proved to be sensitive to both antibiotics. Most strains of Staphylococcus aureus and of Salmonella were sensitive to both anitibiotics, however, the strains of Proteus and those of Pseudomonas were less sensitive.

Dalaut et al. (1966) described the importance of administering

Received 8th. March, 1974. 
thiamphenicol parenterally in pediatric therapy. Thiampenicol glycinate was adm.niscered intramusculariy and intravenously at varying doses according to the patient's age and severity of the illness. The doses ranged from 20 to $60 \mathrm{mg} / \mathrm{Kg} /$ day or even higher in the acute period.

The maximal total dose used was 21 . $75 \mathrm{Gm}$ and the highest one was 153 $\mathrm{mg} / \mathrm{Kg} /$ day administered intravenously in a 25-day-old baby.

Goto and Kawahara (1966) made a comparative study of the anti bacterial activity in vitro of thiamphenicol and chloramphenicol and found that the bacteriostatic potency of the two antibiotics were quantitatively identical as regards Streptococcus pyogenes and mitis, Diplococcus pneumoniae, Corynebacterium diphtheriae, Brucella meltensis, Shigella and Vibrio Eltor.

Bordetella pertussis showed greater sensitivity to thiamphenicol; Streptococcus fecalis, Staphylococcus aureus and epidermidis, E. coli and Salmonella ityphi were more sensitive to chloramphenicol.

Induction of resistance in vitro showed that strains of Shigella and Vibrio Eltor having become resistant to one antibiotic, presented a crossresistance to others; whereas Staphyloccoccus aureus and E. coli having developed resistance to thiamphenicol remained sensitive to chloramphenicol, but those resistant to chloramphenicol were invariably resistant to thiamphenicol.

The aim of this study is to evaluate the clinical responses of the thiamphenicol in bronchopneumonia in children under 2 years of age, who were hospitalized in the Departmen:s of Child Health, Dr. Tjipptomangunkusumo General Hospital, in comparison with Penicillin-Chloramphenicol.

\section{Material and method}

Our observations covered a total of 131 cases between ages of $O$ month and 2 years during February until March 1970, who were hospitalized in the Dr. Tjiptomangunkusumo General Hospital, suffering from bronchopneumonia duplex. The groups studied were formed by dividing into two groups alternatingly by the sequence of the admittance to the hospital.

Group I was treated with Thiamphenicol at a dose of $75 \mathrm{mg} / \mathrm{Kg} /$ day parenterally (intravenously/intramuscularly) for the first 3 days followed by the same dosage orally till the 7 th day to the 10 th day.

To group II Penicillin G Procain was given at a dose of $50.000 \mathrm{U} / \mathrm{Kg}$ / day combined with chloramphenicol parenterally $75 \mathrm{mg} / \mathrm{Kg} /$ day for the first and the second day, followed by chloramphenicol orally for the following 7 to 10 days. .

Supportive treatment such as oxygen, aspiration of the mucosecretion were given to both groups. 
For assuring the intake of liquid and calorie during the first $2 \times 24$ hours, intravenous fluid drip were instituted equally to both groups. The diagnosis was established based on the sympitoms, routine laboratory examinations and radiological findings.

The clinical parameters taken into consideration for the evaluation of the clinical effects of both treatments were:

the disappearance of fever and respiratory symptoms (dyspnea, alae nasi respiration, cyanosis).

Relapse and complications were evaluated among both groups. The radiological and microbiological improvements were not evaluated during this study.

Table 2 illustrates the etiology of bronohopneumonia among children who were hospitalized in the Dr. Tjiptomangunkusumo General Hospital (January up to May 1970 by Harry Hardjatno and Tagor). Sixty five cases in the first group and 66 cases in the second group were collected during 4 months.

In every group classification has been made based on the clinical response. The disappearance of fever after ithe lst day to the third day of treatment and the afebrile condition sustained for 2 or 3 following days, with the improvement of the respiratory sympitoms were considered as excellent. The disappearance of the fever after 4 to 6 days, 6 to 10 days, 10 to 14 days, and more than
14 days were considered as good, fair, bad, and failure respectively.

\section{Results}

From Group I, 56 cases of excellent to good were found from the total cases of $65 ; 59$ cases of excellent to good were found from the total cases of the 66 in the second group (table $3)$. Seven cases considered as fair to bad were found in both groups. Two cases were considered as failure in the first group, in which the symptoms persisted after 14 days, one case with asthma bronchiale as underlying disease and the other one showed Mantoux test conversion in the repeated itests. One case considered as failure in the second group showed radiologically atelectasis of the upper-right segment of the lung.

Table 3 shows the diagram of the results of this study, and table 4 indicates the concomittant disease and nutritional condition of the patients.

Otitis media acuta was found in 21 cases among Group I, and 16 cases in Group II. There were no complicaltions in the form of pleural effusion, empyema, abscess of the lung, meningitis, endocarditis, pericarditis and arthritis in this material.

Complications in the form of delayed resolution (physical and radiological findings of the lungs that persist after 21 days or more after the disappearance of fever) could be found. It could be reported, however, 
that on 27 cases from Group I, and 16 from Group II with delayed resolution, further investigation could not be done because the patients refused to cooperate for a longitudinal study.

\section{Discussion}

The use of Thiamphenicol intramuscularly, intravenously and orally in the treatment of bronchopneumonia in children was studied in comparison with Penicillin-chloramphenicol treatment for the same affection.

The treatmen't was given until remission of the sympitoms was obtained. From the clinical point of view there were no appreciable differences between the results achieved by the two medicamentations.

Five cases of relapse were found from 65 cases of Group I in comparison with 2 relapses from 66 cases of Group II; 27 cases showed complication in the form of delayed resolution from Group I against 16 from Group II.

The mortality was almost equal, there were 3 in Group I and 2 in Group II. Results of treatment of pneumonia in children with urfamycin by various authors is presented in table 1.

\section{Summary and Conclusions}

In this study the authors tried to eompare Urfamycin with Penicillinchloramphenicol in the treatment of bronchopneumonia in children.
There were no important differences between the results obtained by Ur. famycin alone and Penicillin-chloramphenicol.

The bacterial spectrum covered by Thiamphenicol and Chloramphenicol was similar. However, some strains showed greater sensitivity in vitro to chloramphenicol and less induction of resistance. In general no undesirable secondary reactions were observed, in the form of hematopoietic suppression (especially erythropoietic suppression) in boith treatments.

Concerning the clinical response, price and availability of the drug, the authors concluded :

1. For those hospitals which are always fully occupied by patients with severe Bronchopneumonia, Penicillin-Chloramphenicol should still be considered as the drug of choice.

2. Although both treatments have achieved good results, there are no important differences clinically and microbiologically between Thiamphenicol and PenicillinChloramphenicol.

3. The advantage of Thiamphenicol is only in its taste which is acceptable for children.

4. Thiamphenicol is used as a single drug and can be administered to those patients with hypersensitivity to Penicillin groups. 


\section{THIAMPHENICOL (Urfamycin)}

The chemical designation for thiamphenicol is $\mathrm{D}(+)$-threo-2-di-choloroacetamido-1-(4methylsulphonylphenyl) propane-1,3-diol.

Its structural formula is the following.

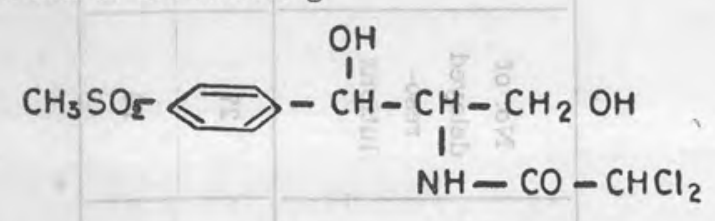

\section{Empirical formula: $\mathrm{C}_{12} \mathrm{H}_{15} \mathrm{Cl}_{2}$ NOs Molecular weight: 356.24}

Inptrical formula: $\mathrm{C}_{12} \mathrm{H}_{15} \mathrm{Cl}_{2} \mathrm{NO}_{5} \mathrm{~S}$ Molecular wetght: 356.24

TABLE 1: Treatment of pneumonia in children with Urfamycin (Systemic only).

In parentheses, number of favourable results over number of cases treated :

LOSCIALPO RAMUNDO D.

PODDINE G. et al

$16 / 16$

VASSINA E.

$19 / 22$

VASSINA E.

$54 / 58$

HARDJATNO H. CH.

$36 / 38$

$60 / 65$

TABLE 2: Survey of etiologic agents (throat swab) an children with bronchopneumonia, hospitalized in the Dr. Tjipiomangunkusu mo Hospital (January - May 1970).

\begin{tabular}{c|c|c|c|c|c}
\hline $\begin{array}{l}\text { Pathogens isolated } \\
\text { (before treatment) }\end{array}$ & $\begin{array}{c}\text { Pneumo- } \\
\text { cocc. }\end{array}$ & $\begin{array}{c}\text { Pneumo- } \\
\text { cocc. } \\
\text { Staphylo- } \\
\text { cocc. }\end{array}$ & $\begin{array}{c}\text { Pneumo- } \\
\text { Strepto- } \\
\text { cocc. }\end{array}$ & $\begin{array}{c}\text { Non-Pneu- } \\
\text { mococc. }\end{array}$ & $\begin{array}{c}\text { Hemopht. } \\
\text { lus } \\
\text { group }\end{array}$ \\
\hline No. of patients & 8 & 25 & 34 & 16 & 4 \\
\hline
\end{tabular}

Organisms showing resistency to Urfamy cin:

some strains of Pneumococc.

Staphylococcus aureus hemolyticus

Aerobacter aerogenes

Pyocyaneus B.

some strains of Streptococcus anhemolyticus

some strains of Streptococcus hemolyticus

E. coli

Friedlander b. 
TABEL 3: Comparative clinical Responses of Bronchopmeumonia in children treated with urfamycin (Group I) and with Penicillin in combination with chloromycetin (Group II) anid case

fatality.

\begin{tabular}{|c|c|c|c|c|c|c|c|c|c|c|}
\hline \multirow{2}{*}{ Group No. } & \multirow[b]{2}{*}{ Excellent } & \multicolumn{3}{|c|}{ Clinical Response } & \multirow{2}{*}{ Failure } & \multirow{2}{*}{$\frac{1}{2}$} & \multicolumn{2}{|c|}{$\begin{array}{l}\text { No. of fatal } \\
\text { cases }\end{array}$} & \multirow{2}{*}{$\begin{array}{l}\text { No. of } \\
\text { delayed } \\
\text { reso- } \\
\text { lutions }\end{array}$} & \multirow{2}{*}{$\begin{array}{c}\text { No. of } \\
\text { relap } \\
\text { se }\end{array}$} \\
\hline & & Good & Fair & Bad & & & $\begin{array}{c}4-24 \\
-3\end{array}$ & $\begin{array}{c}24 \\
\text { hours }\end{array}$ & & \\
\hline I $\quad 65$ & 33 & 23 & 4 & 3 & 2 & - & 1 & 2 & 27 & 5 \\
\hline II $\quad 66$ & 32 & 27 & 2 & 4 & 1 & - & - & 2 & 16 & 2 \\
\hline
\end{tabular}


TABEL 4: Concomittant diseases and nutritional conditions in children hospitalized for bronchopneumonia.

\begin{tabular}{l|c|c|c|c|c}
\hline Group & $\begin{array}{c}\text { No. of } \\
\text { eutrophic } \\
\text { cases }\end{array}$ & $\begin{array}{c}\text { No. of mal- } \\
\text { nourished }\end{array}$ & $\begin{array}{c}\text { No. of case. } \\
\text { with frequ- } \\
\text { ent URTI* }\end{array}$ & $\begin{array}{c}\text { No. of cases } \\
\text { with } \\
\text { PCM }\end{array}$ & $\begin{array}{c}\text { No. of cases } \\
\text { with } \\
\text { CHD }\end{array}$ \\
\hline I & 21 & 42 & 29 & 2 & 1 \\
\hline II & 26 & 39 & 26 & 1 & - \\
\hline
\end{tabular}

* URTI $=$ Upper Respiratory Tract Infection

$\mathrm{PCM}=$ Protein Calorie Malnutrition

$\mathrm{CHD}=$ Congenital Heart Disease

\section{REFERENCES}

1. COURTIEU, A.L.; LONGERAY C.; MIRAILLET, C.; COLOMBET M.F. and BADIOU A. : Sensitivity of different kinds of Bacteria to Thiamphenicol. Ann. Inst. Pasteur 101: 47 (1961).

2. DALAUT, J.J.; MANCIAUX, M.; GURECKI, $H$. and NEIMANN, N. The importance of parenteral Thiamphenicol in Pediatric Therapy.

Ann. Med. Nancy 5: 781 (1966).

3. GOTO, S. and KAWAHARA, S. : Antibiosis of Thiamphenicol. Chemotherapy (Japan) $14: 435$ (1966).

4. HARRY HARDJATNO, $\mathrm{CH}$. and TAGOR, A.H. : (unpublished data 1970).

5. LOSCIALPO RAMUNDO, D. : Observation Concerning the treatment of Broncho-alveolitis in newborn Infants with Thiamphenicol Glysinate. Clin. pediat. 48 : 402 (1966), Communication to the XXXI National Conggress of the Italian Pediatric Society - Genova 1966.

6. PODDINE, G., UGOLINI, A. and LA ROCCA, I. : Clinical Experience with Thiamphenicol. Aggiorn Pediat. 12 : 261 (1961).

7. VASSENA, E.: Considerations on the treatment with Thiamphenicol of Acute Respiratory Infections in Early Infancy. Clin. pediat. 42 : 215 (1960); Clinical Experience with Thiamphenicol Glycinate in Early Infancy. Gaz. mẹ. ital. 121 : 218 (1962). 